Students in India object to AIDS test

\section{New Delhi}

THERE is no indication that the Indian government will reverse its decision on compulsory tests for AIDS (acquired immune deficiency syndrome).

The Minister for Human Resource Development, Mr P.V. Narasimha Rao, told the Indian parliament on 25 February that the screening of foreign students for AIDS would continue. Rao ignored suggestions from Members of Parliament that this discriminatory practice could spoil India's relations with African countries. He said AIDS is a serious matter and that the government has decided to deport foreign students who carry the AIDS virus. He also rejected a suggestion that serum samples suspected to be positive for AIDS, on the basis of tests carried out in India, should be sent abroad for confirmation.

Africans, who constitute more than 80 per cent of the estimated 30,000 foreign students, feel the test is directed at them and say it is racist. The foreign student community does not oppose tests on new entrants but is against screening those who have studied in India for several years.

Foreign students of Bombay University failed to turn up for the test scheduled for 16 February. The screening was postponed to 22 February but the International Students Association decided that none of its members would take the test unless local students were also included. Foreign students at Delhi University have also boycotted the test.

Fear, social ostracism and the psychological trauma of being singled out as prospective AIDS carriers have put the educational career of the Africans in jeopardy, their student leaders allege. They say they are shunned by their former Indian friends in the universities, in their apartments and by tradesmen. The Africans fear expulsion from the universities on the basis of unreliable tests showing false positives, or tests conducted by non-experts. They claim that three Kenyan students deported recently from India were found to be AIDS-free in more accurate tests carried out by experts back in Kenya.

The students are agitated because they have been told that failure to take the test would prevent them taking the annual examinations, barely a month away.

Some 1,500 African students who have refused to undergo the test were planning a protest march in New Delhi on 27 February, and it was expected that a large number of sympathizers would attend.

India has so far detected 92 cases of AIDS infection, five of whom died in the past year.

K.S. Jayaraman

\title{
Extra MRC funds earmarked for AIDS research in Britain
}

\section{London}

BRITrSH scientists have persuaded the government to increase the budget of the Medical Research Council (MRC) by $£ 14.5$ million over three years for research into the prevention and cure of AIDS (acquired immune deficiency syndrome). Most unusually for the MRC, the research is to be centrally directed in an effort to maximize its efficiency.

There will be two programmes of research, one on vaccines and the other on drugs. Each will be organized by a separate director who has yet to be appointed. More of the money is expected to be spent on vaccine research than on drug research, says the MRC's secretary Sir James Gowans, not least because the drug research is more likely to attract industrial sponsorship. $£ 2.5$ million will be available for both programmes this year, with $£ 5$ million next year and $£ 7.5$ million in 1989 . Gowans says he has received assurances of longer-term funding.

The two directors will be responsible for commissioning the various strands of their programmes of research. Much of the research will probably be concentrated in three or four large centres with smaller, specific projects being commissioned elsewhere. Both Gowans and Mr Norman Fowler, Secretary of State for Social Services, emphasized that contracts will go to the most appropriate laboratories,

\section{Compulsory AIDS testing in Bavaria \\ Hamburg}

ANYBODY suspected of being infected by human immunodeficiency virus (HIV), the cause of AIDS (acquired immune deficiency syndrome), will soon be compelled by the Bavarian authorities to undergo a test.

The decision was made by the cabinet (Ministerrat) of the Bavarian Land government on 25 February. If such people do not appear for testing the health authorities and police will force them to do so.

Male and female prostitutes fall into the risk category, as does anybody seen talking to them. Prisoners and those held on remand are also compelled to take the test. Furthermore, candidates for the civil service will be tested, and anybody whose test proves positive will be rejected.

The other states of the federal republic have criticized the tough stance of Bavaria. The federal minister of health, Rita Süssmutt (Christian Democrat), said that this was the wrong way to deal with the disease. The Social Democrats called the Bavarian initiative "ineffective and hardly acceptable". whether they are academic or industrial.

The proposals that attracted these funds were put together by the MRC after consultations with scientists, many of whom would be keen to play a part in the project. Gowans was closely involved in the consultations on vaccine research, while Sir David Phillips, chairman of the Advisory Board for the Research Councils and a leading protein crystallographer, chaired a recent and hurried meeting of molecular biologists with a potential interest in exploring viral proteins that could be targets for drugs against AIDS. Both sides agreed that the two major limiting factors in AIDS research are the lack of sufficient quantities of viral proteins either to be tested as vaccines or to be crystallized for structural studies and the lack of convenient animal models.

Speaking at MRC's press briefing, Professor William Jarrett of the University of Glasgow, said that some of the funds earmarked for vaccines will have to be spent on animal testing facilities. Chimpanzees and, perhaps, gibbons are the only animals that can currently serve as models but the recent report of an HIV-type of virus associated with an AIDS-like syndrome in cats was hopeful. He believed there would soon be immunity trials of subunit vaccines in man. Gowans volunteered himself for such a trial.

At least two laboratories have expressed an interest in filling the need for large quantities of viral proteins. One is the Public Health Laboratory Service Centre for Applied Microbiology and Research, at Porton, which already produces viral antigen for Wellcome's AIDS test. The centre's director, Dr Peter Sutton, has already discussed with MRC how the centre might help. The other is the Natural Environment Research Council's Institute of Virology in Oxford which has expertise in the use of engineered baculoviruses for the production of large quantities of proteins. Its director, Professor David Bishop, is waiting to hear whether the $\mathrm{MRC}$ is interested in this project. If not, he has commercial backers in the wings.

Research on the proteins, once available, is likely to proceed in various laboratories. Dr John Skehel's division of virology at the MRC's National Institute of Medical Research is already working on the envelope glycoprotein in conjunction with crystallographer Don Wiley at Harvard. And Professor Tom Blundell's group at Birkbeck college in London is particularly interested in the proteinase of the virus, which has some relationship to proteinases of known structure. One centre for vaccine research seems certain to be Jarrett's laboratory. Peter Newmark 